\title{
Serological and Molecular Characterization of Mesoplasma seiffertii Strains Isolated from Hematophagous Dipterans in France
}

\author{
OLIVIER GROS,${ }^{1}$ COLETTE SAILLARD, ${ }^{2}$ CATHERINE HELIAS, ${ }^{1}$ FRANCETTE LE GOFF, ${ }^{1}$ \\ MICHEL MARJOLET, ${ }^{3}$ JOSEPH M. BOVÉ, $^{2}$ AND CLAUDE CHASTEL ${ }^{1 *}$ \\ Laboratoire des Virus, Faculté de Médecine, 29285 Brest Cedex, ${ }^{1}$ Laboratoire de Biologie Cellulaire et Moléculaire, \\ Institut National de la Recherche Agronomique and Université Bordeaux II, 33883 Villenave-d'Ornon Cedex, ${ }^{2}$ and \\ Laboratoire de Parasitologie et Pathologie Exotique, Faculté de Médecine, 44035 Nantes Cedex, ${ }^{3}$ France
}

\begin{abstract}
Three strains of nonhelical mollicutes previously isolated in France from two different mosquitoes and one tabanid fly were designated strains Ar 2328 (isolated from Aedes detritus), Ar 2392 (isolated from Aedes caspius), and CP 13 (isolated from Chrysops pictus). All of these strains exhibited properties of the genus Mesoplasma, a recently described genus of non-sterol-requiring mollicutes isolated from plants and insects. The results of metabolism inhibition and growth inhibition tests revealed that these strains and Mesoplasma entomophilum TAC or Mesoplasma florum $\mathbf{L} 1$ were not serologically related, but all three dipteran strains reacted strongly with Mesoplasma seiffertii $\mathrm{F}^{\mathrm{T}}$ ( $\mathrm{T}=$ type strain) antibodies. Using metabolism inhibition and growth inhibition tests, we found that the dipteran strains were related to each other and to strain $F 7^{\mathrm{T}}$ but were not identical. We also found that they were able to multiply and persist in the central nervous systems of suckling mice inoculated intracerebrally, a property that makes their use as biological control agents for pest dipterans inadvisable. Scanning electron microscopy revealed marked differences in the morphologies of the colonies of the different strains on SP4 solid medium. The levels of DNA-DNA homology for strains Ar 2328, Ar 2392, CP 13, and F7 were more than $70 \%$, indicating that these strains are closely related members of the same species, $M$. seiffertii. In addition, one-dimensional sodium dodecyl sulfate-polyacrylamide gel electrophoresis revealed that each strain produced about $\mathbf{4 0}$ protein bands. This technique also revealed differences between strains. Using the coefficient of Smeath-Jacquart, we constructed a dendrogram that allowed us to estimate of the levels of relatedness of these four strains. The results which we obtained were confirmed by two-dimensional protein electrophoresis results.
\end{abstract}

During ecological studies performed in 1988 and 1990 on mosquito and tabanid spiroplasmas in Parc Régional de Brière in western France $(14,15)$, three strains of nonhelical mollicutes were isolated unexpectedly; two of these strains were isolated from the marsh mosquitoes Aedes detritus Haliday 1833 and Aedes caspius Pallas 1771, which were collected in ancient salt marshes, and one was isolated from the deerfly Chrypsos pictus Meigen 1820, which was collected in a nearby forest biotope. As preliminary serological screening revealed that these strains were apparently related to a plant mollicute, Mesoplasma seiffertii, they were compared with this organism by using both serological and molecular methods.

An important question about Mesoplasma seiffertii is its pathogenicity for plants and animals, including humans. The answer to this question is not known, but the fact that strains of this mollicute were isolated from hematophagous insects suggests that it deserves attention.

Another interesting question is the possible use of dipteran strains of Mesoplasma seiffertii as biological control agents for hematophagous insects. In this regard Aedes caspius may be a prime target since it is the vector for many arboviruses and filariae. For instance, Tahyna virus, a bunyavirus belonging to the California encephalitis group, was isolated from this mosquito species in the former Czechoslovakia in 1959 (2) and later was isolated in many other countries of Eurasia, including France (10), where it is responsible for a febrile illness, especially in children. Other viruses, including Issik-Kul, Isfahan, and Batken viruses, have also been isolated in the former

\footnotetext{
* Corresponding author.
}

USSR (12) from this mosquito species, which is also the vector of two canine filariae, Dirofilaria immitis and Dirofilaria repens; these two helminths may accidentally infect humans. In contrast, no role as a vector has been described for Aedes detritus (12) or Chrypsos pictus $(9,13)$, but these organisms are major pests of human beings and animals.

\section{MATERIALS AND METHODS}

Mycoplasma strains. The type strain of Acholeplasma seiffertii, strain F7, was isolated in 1980 from the surfaces of Citrus sinensis flowers from Morocco (3). Recently, Acholeplasma seiffertii was transferred to a new genus of the class Mollicutes, the genus Mesoplasma, and was renamed Mesoplasma seiffertii; the following three other species were also assigned to this genus: Acholeplasma entomophilium, Acholeplasma florum, and Mycoplasma lactucae (22). Strains Ar 2328, Ar 2392, and CP 13 were isolated from the whole bodies of the mosquitoes Aedes detritus and Aedes caspius (14) and the deerfly Chysops pictus (15), respectively.

Media, cultivation, and purification. Type strain F7 and the three dipteran Media, cultivation, and purification. Type strain F7 and the three dipteran
strains were isolated previously by using SP4 medium (24), and strains Ar 2328, Ar 2392, and CP 13 were cloned three times before they were characterized. All of the strains were maintained in SP4 medium.

Characterization studies. Cell morphology was determined by dark-field microscopy and electron microscopy. For scanning electron microscopy, colonies on solid SP4 medium were fixed in $2.5 \%$ glutaraldehyde in cacodylate buffer, dehydrated through a graded acetone series, critical point dried in liquid carbon dioxide (with a Balzers model CPD 020 apparatus), and coated with goldpalladium (Humer V; Technics). Filterability was determined by using membrane filters having a pore diameter of $220 \mathrm{~nm}$. The ability to metabolize glucose, arginine, and urea was determined in heart infusion broth (Difco) as described previously (1); we used Spiroplasma taiwanense $\mathrm{CT}^{\mathrm{T}}$ ( $\mathrm{T}=$ type strain) $\left(\mathrm{Glu}^{+}\right.$ $\mathrm{Arg}^{-}$) and Spiroplasma sabaudiense $\mathrm{Ar} 1343^{\mathrm{T}}\left(\mathrm{Glu}^{+} \mathrm{Arg}^{+}\right)$as controls. SP4 media inoculated with each strain were incubated at 30 and $37^{\circ} \mathrm{C}$ without shaking, and titration values were expressed in color-changing units per milliliter. The sterol and fatty acid requirements of the four strains which we studied were determined by a recently described method (21).

Serological tests. The rabbit antisera prepared against Mesoplasma seiffertii, 

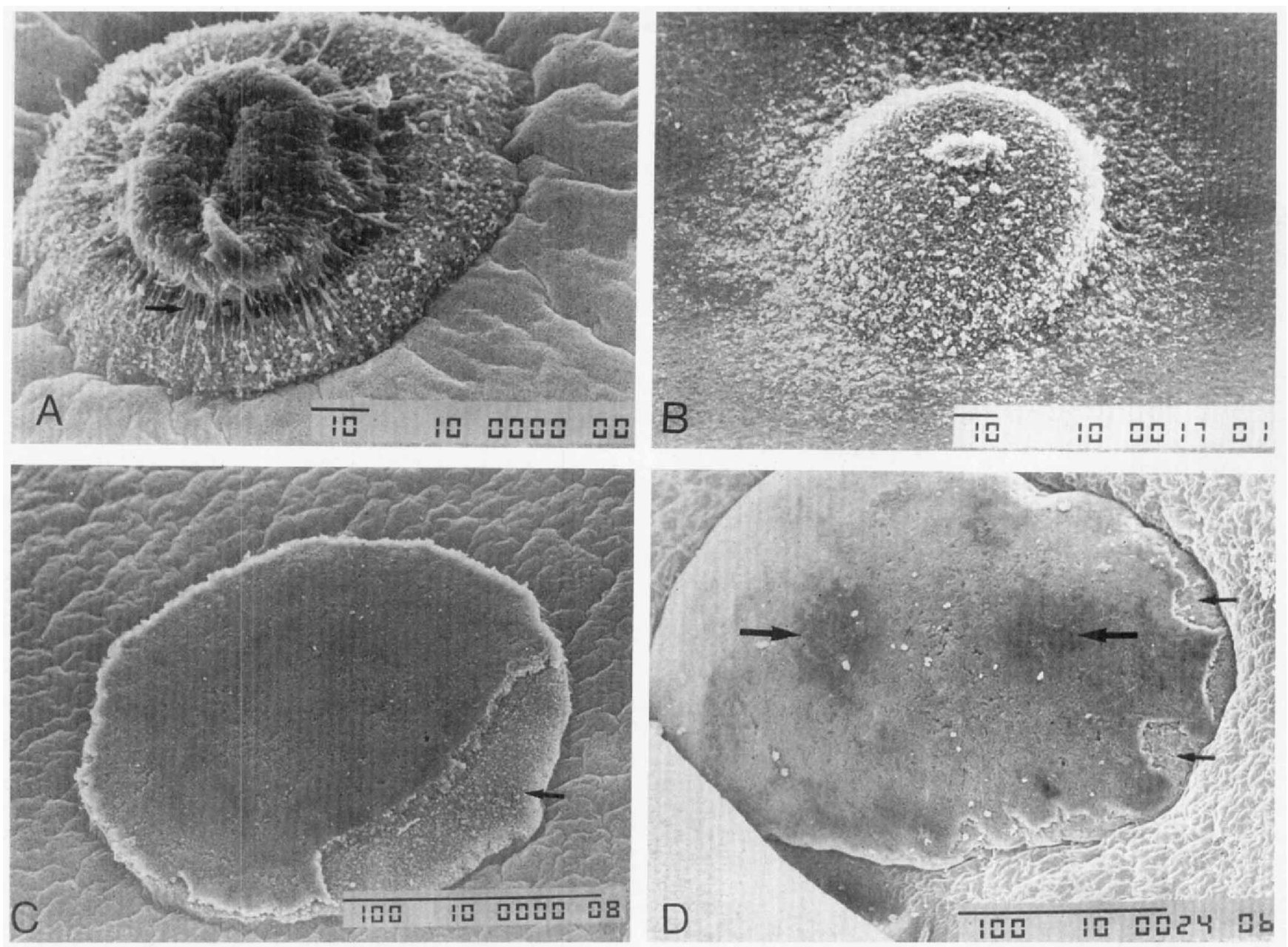

FIG. 1. Scanning electron microscopy of Mesoplasma seiffertii colonies after 10 days of incubation at $30^{\circ} \mathrm{C}$ on solid SP4 medium. (A) Strain F $7^{\mathrm{T}}$. The arrow indicates filaments that link the two areas of a typical fried-egg colony. Magnification, $\times 900$. (B) Strain CP 13. Magnification, $\times 450$. (C) Strain Ar 2392. The arrow indicates Mesoplasma cells in a protruding area. Magnification, $\times 120$. (D) Strain Ar 2328. The large arrows indicate hillocks which can be observed better by light microscopy, - and the small arrow indicate Mesoplasma cells in a protruding area. Magnification, $\times 60$.

Mesoplasma entomophilum, and Mesoplasma flonum that were used for preliminary screening were kindly supplied by J. G. Tully, National Institute of Allergy and Infectious Diseases, Frederick, Md. Antibody to Mesoplasma lactucae was not available.

Mouse immune ascitic fluid for strain $\mathrm{F}^{\mathrm{T}}$ and each dipteran strain was prepared by using the protocol of the Yale Arbovirus Research Unit, New Haven, Conn. Briefly, 6-week-old female Swiss EOPS mice (Etalb. Janvier, Le GenestSaint-Isle, France) were immunized against each of the four strains. The mice were inoculated intraperitoneally four times at 10-day intervals and then received Ehrlich ascitic tumor fluid intraperitoneally. Antibodies were collected at the peak of ascite formation (generally 12 to 15 days later).

Growth inhibition and metabolism inhibition tests $(7,19)$ were performed concurrently in order to compare the four strains serologically.

Pathogenesis studies. The multiplication and persistence of each strain were studied by using the suckling mouse model that was developed to determine the pathogenicity of bee and tabanid spiroplasmas for the central nervous system (4, 5).

Electrophoresis of proteins. A $100-\mathrm{ml}$ portion of a culture of each strain was centrifuged for $30 \mathrm{~min}$ at $9,000 \times g$ and $4^{\circ} \mathrm{C}$ and then washed three times with 10 $\mathrm{ml}$ of sterile water, and the pellet was resuspended in 8 to 10 volumes of lysis buffer ( $2 \%$ Triton X-100, $2 \%$ mercaptoethanol, $2 \%$ ampholyte solution [pH 3 to 10; Pharmacia, Uppsala, Sweden], $9 \mathrm{M}$ urea, $8 \mathrm{mM}$ phenylmethylsulfonyl fluoride). The resulting preparation was subjected to four cycles consisting of $5 \mathrm{~min}$ on ice and $1 \mathrm{~min}$ of bead beating in the presence of $0.5 \mathrm{~g}$ of 0.1 -mm-diameter zirconium beads. The sample was then centrifuged at $30,000 \times g$ for $45 \mathrm{~min}$ at $4^{\circ} \mathrm{C}$. The resulting supernatant was considered the protein fraction. The protein concentration was determined by using a protein assay kit (Sigma Chemical Co. St. Louis, Mo.) that was based on a modification of the method of Lowry et al. (16).

For one-dimensional sodium dodecyl sulfate (SDS)-polyacrylamide gel electrophoresis (PAGE) we used SDS-polyacrylamide geis $(16 \mathrm{~cm}$ by $14 \mathrm{~cm}$ by $1 \mathrm{~mm}$; the running gel contained $12 \% \mathrm{~T}$ and $2.6 \% \mathrm{C}$, and the stacking gel contained $4 \%$ $\mathrm{T}$ and $2.6 \% \mathrm{C}$ ). Samples of each preparation were diluted in SDS sample buffer $(1.52 \mathrm{~g}$ of Tris base, $2 \mathrm{~g}$ of SDS, $1 \mathrm{mg}$ of bromophenol blue, $20 \mathrm{mI}$ of glycerol, 40 $\mathrm{ml}$ of distilled water) to a concentration of $25 \mu \mathrm{g} / 10 \mu \mathrm{l}$ and then boiled for $3 \mathrm{~min}$ and loaded into wells. Electrophoresis was performed in a Protean II electrophoresis tank (Bio-Rad, Richmond, Calif.) until the migration front had migrated $14 \mathrm{~cm}$ at a limiting power of $1 \mathrm{~W}$ per plate (stacking gel) or $5 \mathrm{~W}$ per plate (running gel).

For two-dimensional gel electrophoresis (NEPHGE) we used a technique derived from the original method of O'Farrell et al. (18). Samples containing 100 $\mu \mathrm{g}$ of proteins were focused at $4,000 \mathrm{~V} / \mathrm{h}$ and then for $1 \mathrm{~h}$ at $400 \mathrm{~V}$ and for $4 \mathrm{~h}$ at $800 \mathrm{~V}$ in glass tubes (diameter, $1.2 \mathrm{~mm}$ ), which produced $13-\mathrm{cm}$-long gels which contained $9.6 \% \mathrm{~T}$ and $12 \% \mathrm{C}$. The ampholytes used were $\mathrm{pH} 5$ to $8, \mathrm{pH}$ 3 to 10 , and $\mathrm{pH} 8$ to 10.5 ampholytes (Pharmacia) at a ratio of $5: 3: 1$. The gels were extruded and loaded onto a square SDS-polyacrylamide gel (the running gel contained $12 \% \mathrm{~T}$ and $2.6 \% \mathrm{C}$, and the stacking gel contained $4 \% \mathrm{~T}$ and $2.6 \%$ C). Electrophoresis in the second dimension was performed in a Protean II electrophoresis tank as described above for one-dimensional electrophoresis.

The one- and two-dimensional electrophoresis gels were silver stained as described by Heukeshoven and Dernick (11).

Genomic comparison. DNA-DNA hybridization was performed by previously described methods (8).

\section{RESULTS}

Cultural and morphological properties. The four strains which we studied grew rapidly and extremely well in SP4 medium, usually reaching the peak logarithmic phase in 8 to $10 \mathrm{~h}$ 
TABLE 1. Comparison of Mesoplasma seiffertii CP 13, Ar 2392, Ar 2328 , and $F 7^{\mathrm{T}}$ by metabolism inhibition and growth inhibition tests

\begin{tabular}{lllll}
\hline \multirow{2}{*}{ Antigen } & \multicolumn{4}{c}{$\begin{array}{c}\text { Metabolism inhibition test results (growth inhibition } \\
\text { test results) }\end{array}$} \\
\cline { 2 - 5 } & $\begin{array}{c}\text { Strain } \\
\text { CP 13 } \\
\text { antibody }\end{array}$ & $\begin{array}{c}\text { Strain } \\
\text { Ar 2328 } \\
\text { antibody }\end{array}$ & $\begin{array}{c}\text { Strain } \\
\text { Ar 2392 } \\
\text { antibody }\end{array}$ & $\begin{array}{c}\text { Strain } \\
\text { F } 7^{\mathrm{T}} \\
\text { antibody }\end{array}$ \\
\hline CP 13 & $1 / 128(2)$ & $1 / 32(0)$ & $1 / 256(0)$ & $1 / 512(3)$ \\
Ar 2328 & $1 / 64(0)$ & $1 / 256(1)$ & $1 / 64(1)$ & $1 / 64(0)$ \\
Ar 2392 & $1 / 64(0)$ & $1 / 64(0)$ & $1 / 512(2)$ & $1 / 256(0)$ \\
F7 $^{\mathrm{T}}$ & $1 / 64(2)$ & $1 / 32(0)$ & $1 / 256(1)$ & $1 / 512(4)$ \\
\hline
\end{tabular}

at 30 and $37^{\circ} \mathrm{C}$. On solid SP4 medium, growth was observed after 10 days; only strains $\mathrm{F}^{\mathrm{T}}$ and $\mathrm{CP} 13$ produced typical fried-egg colonies. Moreover, scanning electron micrographs revealed specific morphological characteristics of each strain (Fig. 1). Individual cells in the colonies were spherical (mean diameter, about $500 \mathrm{~nm}$; range, 300 to $1,000 \mathrm{~nm}$ ), whereas cells in liquid SP4 medium exhibited typical mollicute pleomorphism. The cells of each strain passed through a 220 -nm-poresize filter.

Biochemical properties. All four strains which we studied fermented glucose, hydrolyzed arginine but not urea, and were able to grow in serum-free mycoplasma broth containing Tween 80; thus, they exhibited biochemical properties consistent with inclusion in the genus Mesoplasma, family Entomoplasmataceae, and order Entoplasmatales (22).

Serological tests. During preliminary screening each dipteran strain reacted strongly with Mesoplasma seiffertii antibody; the titers were 1:96 for strain CP 13,1:384 for strain $\mathrm{Ar}$ 2328, and 1:192 for strain Ar 2392. Tests in which Mesoplasma entomophilum and Mesoplasma florum antibodies were used were negative (titers, $<1: 12$ ).

The results of growth inhibition and metabolism inhibition tests performed with $\mathrm{F}^{\mathrm{T}}$ and the three other strains which we studied are shown in Table 1. All of the strains cross-reacted with each other, but the levels of the cross-reactions were variable. Our results showed that there was antigenic heterogeneity, especially in the growth inhibition tests.

Electrophoretic analysis. We observed about 40 protein bands for each strain after one-dimensional electrophoresis

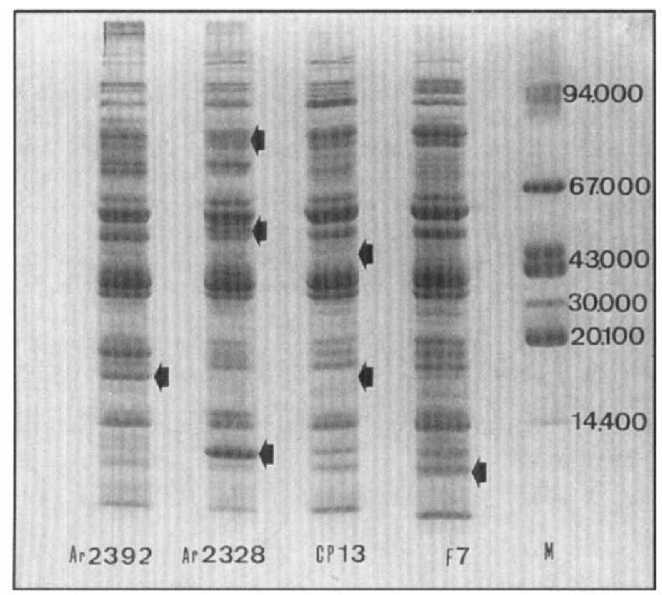

FIG. 2. One-dimensional electrophoresis profiles on a $12 \%$ polyacrylamide gel of total proteins from Mesoplasma seiffertii $\mathrm{Ar} 2392$. Ar 2328. CP 13, and $\mathrm{F}^{\mathrm{T}}$ The arrows indicate some striking differences in the profiles.

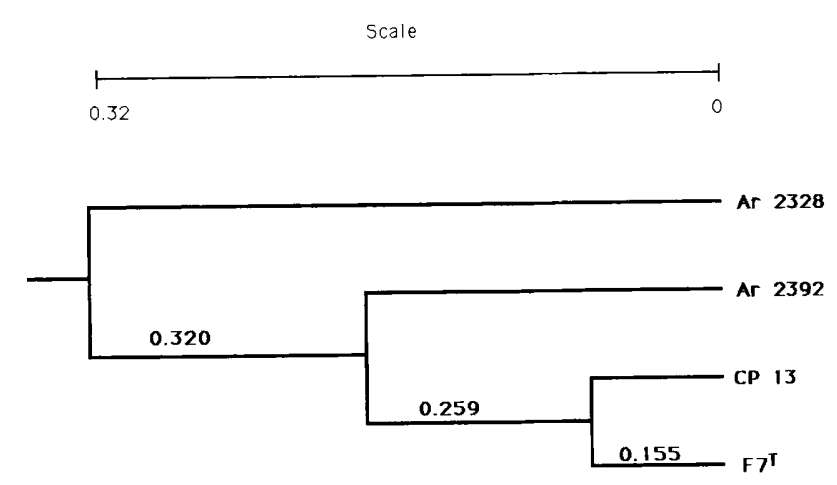

FIG. 3. Dendrogram constructed by using the Smeath-Jacquard coefficient after an analysis of the profiles of Mesoplasma seiffertii Ar 2392, Ar 2328, CP 13, and $\mathrm{F}^{\mathrm{T}}$ (see Fig. 2).

(Fig. 2), and there were differences in the migration profiles of the strains studied. Using the Smeath-Jacquart coefficient, we constructed a dendrogram which allowed us to estimate of the levels of relatedness of the strains (Fig. 3). In fact, deerfly strain CP 13 appeared to be more closely related to strain $F 7^{T}$ than the mosquito strains were; the most distantly related organism was apparently strain Ar 2328 (the strain isolated from Aedes detritus). These results were confirmed by the results of two-dimensional protein electrophoresis (data not shown).

DNA-DNA hybridization. The DNA-DNA hybridization results are shown in Table 2 . As the levels of homology for strains $\mathrm{F}^{\mathrm{T}}$, Ar 2328, $\operatorname{Ar} 2392$, and CP 13 were always more than $70 \%$ (the lowest level of homology was $73 \%$ when high-stringency conditions $\left[39^{\circ} \mathrm{C}\right.$; melting temperature $\left.-12^{\circ} \mathrm{C}\right)$, it is clear that the four strains are closely related members of the same species, Mesoplasma seiffertii.

Pathogenesis studies. Alternate passages in vitro at $37^{\circ} \mathrm{C}$ and in vivo revealed that each of the four strains which we studied was able to multiply and persist in the central nervous systems of suckling mice after intracerebral inoculation. However, strains $\mathrm{F}^{\mathrm{T}}$ and $\mathrm{Ar} 2392$, which persisted after the third intracerebral passage, appeared to be more aggressive than strains CP 13 and Ar 2328, which were lost after the second intracerebral passage (data not shown).

\section{DISCUSSION}

The results of serological tests and DNA-DNA hybridization experiments obviously demonstrated that all four strains which we studied (one strain isolated from the surfaces of plants and three strains isolated from the bodies of different hematophagous dipterans) belong to the same species, Mesoplasma seiffertii (formerly Acholeplasma seiffertii). For the cluster of strains which we studied, genomic analysis is the best method for identifying an individual strain at the species level. However, phenotypic studies performed with the same strains were more informative since the results of a combination of morphological, serological, and pathological tests revealed a notable level of biodiversity in Mesoplasma seiffertil. In fact, variations in the serological properties, pathogenic effects on mice, and morphologies of the colonies as determined by scanning electron microscopy may be interrelated phenomena that are linked, for instance, by the way of a surface antigen(s) is lost or acquired and the presence of a plasmid, phage, etc. Another important problem concerns the pathogenicity of Mesoplasma seiffertii for plants or animals. We are not aware of pathoge- 
TABLE 2. Results of DNA-DNA hybridization experiments performed with Mesoplasma seiffertii $\mathrm{F}^{\mathrm{T}}$, CP 13, Ar 2392, and $\mathrm{Ar} 2328$

\begin{tabular}{|c|c|c|c|c|c|c|c|c|}
\hline \multirow{3}{*}{ Organism } & \multicolumn{8}{|c|}{$\%$ DNA-DNA hybridization ${ }^{a}$} \\
\hline & \multicolumn{2}{|c|}{ Strain $F 7^{\mathrm{T}}$} & \multicolumn{2}{|c|}{ Strain CP 13} & \multicolumn{2}{|c|}{ Strain Ar 2392} & \multicolumn{2}{|c|}{ Strain Ar 2328} \\
\hline & $27^{\circ} \mathrm{C}$ & $39^{\circ} \mathrm{C}$ & $27^{\circ} \mathrm{C}$ & $39^{\circ} \mathrm{C}$ & $27^{\circ} \mathrm{C}$ & $39^{\circ} \mathrm{C}$ & $27^{\circ} \mathrm{C}$ & $39^{\circ} \mathrm{C}$ \\
\hline$\overline{\mathrm{F} 7^{\mathrm{T}}}$ & $100(82)^{b}$ & $100(93.4)$ & 89.3 & 78 & 85 & 96.7 & 89.6 & 89.5 \\
\hline CP 13 & 80.9 & 83.9 & $100(91.6)$ & $100(86)$ & 84.2 & 94.9 & 91.4 & 73 \\
\hline $\mathrm{Ar} 2392$ & 98.2 & 90.4 & 87.7 & 97.7 & $100(96)$ & $100(80.2)$ & 95.1 & 88.6 \\
\hline Ar 2328 & 97.7 & 82.9 & 89.6 & 95.3 & 85.4 & 91.5 & $100(94.6)$ & $100(95.4)$ \\
\hline Escherichia coli & 6.8 & 7.4 & 7.6 & 7.2 & $\mathrm{ND}^{c}$ & 9.9 & 10.5 & 8.9 \\
\hline Spiroplasma citri & 8.6 & 7.8 & 7.4 & 6.9 & ND & 6.4 & 8.6 & 8.6 \\
\hline
\end{tabular}

${ }^{a}$ Averages of three experiments. Hybridization experiments were performed under low-stringency conditions $\left(27^{\circ} \mathrm{C}\right)$ and high-stringency conditions $\left(39^{\circ} \mathrm{C}\right)$.

${ }^{b}$ The values in parentheses are the experimental homologous hybridization values, which were normalized to $100 \%$.

${ }^{c} \mathrm{ND}$, not determined.

nicity for plants, but it is important to note that strain $F 7^{\mathrm{T}}$ was isolated from the surfaces of flowers and could have been deposited there accidentally by scavenging insects. In contrast, strains Ar 2328, Ar 2392, and CP 13 were isolated from the whole bodies and not the surfaces of hematophagous insects. The presence of these microorganisms in insects may represent an opportunity for Mesoplasma seiffertii to be transferred, even by accident (mechanical transmission), to domestic animals and humans. In addition, the four strains are able to multiply in vitro at $37^{\circ} \mathrm{C}$ (the approximate body temperature of mammals) and to multiply and persist in the central nervous systems of inoculated mice.

For the reasons given above, it is obvious that Mesoplasma seiffertii is not a good candidate for a biological control agent for pest dipterans, either mosquitoes or tabanid flies. In fact, mosquito spiroplasmas are better potential biological control agents (4).

Finally, more isolations of Mesoplasma seiffertii strains are needed in order to clarify the general ecology of this organism and its biological cycle in nature, which may involve other hosts. This is also true for the other members of the genus Mesoplasma, including Mesoplasma florum (17), Mesoplasma entomophilum (23), and Mesoplasma lactucae (20), all of which were previously classified as Acholeplasma or Mycoplasma species and were isolated from plant surfaces or insects. Very little is known about the general biology and ecology of these mollicutes.

\section{ACKNOWLEDGMENTS}

This study was supported in part by grant CRE 910603 from the Institut National de la Santé et de la Recherche Médicale, Paris, and by a grant from Fondation Langlois, Rennes, France.

We thank B. Fraigneau for technical assistance in the DNA-DNA hybridization experiments. We also thank Bertrand Picard, Department of Microbiology, Faculty of Medicine, Brest, France, for help with the electrophoretic profile analysis.

\section{REFERENCES}

1. Aluotto, B. B., R. G. Wittler, C. O. Williams, and J. E. Faber. 1970. Standardized bacteriology techniques for the characterization of Mycoplasma species. Int. J. Syst. Bacteriol. 20:35-38

2. Bárdoš, V., and M. Danielová. 1959. The Tahyňa virus-a virus isolated from mosquitoes in Czechoslovaquia. J. Hyg. Epidemiol. Microbiol. Immunol. (Prague) 3:264-276.

3. Bonnet, F., C. Saillard, J. C. Vignault, M. Garnier, P. Carle, J. M. Bové, D. L. Rose, J. G. Tully, and R. F. Whitcomb. 1991. Acholeplasma seiffertii sp. nov., a mollicute from plant surfaces. Int. J. Syst. Bacteriol. 41:45-49.

4. Chastel, C., and I. Humphery-Smith. 1991. Mosquito spiroplasmas. Adv. Dis. Vector Res. 7:149-205.

5. Chastel, C., F. Le Groff, and I. Humphery-Smith. 1991. Multiplication and persistence of Spiroplasma melliferum strain A56 in experimentally infected suckling mouse. Res. Microbiol. 142:411-417.

6. Chastel, C., F. Le Goff, and I. Humphery-Smith. 1992. A tabanid spiroplasma capable of multiplication and persistence in the mouse central nervous system. C. R. Acad. Sci. Paris Ser. III 315:229-233.

7. Clyde, W. A., Jr. 1983. Growth inhibition tests. Methods Mycoplasmol. 1:405-410.

8. Degorce-Dumas, J. R., B. Ricard, and J. M. Bové. 1983. Hybridization between mycoplasma DNAs. Methods Mycoplamol. 1:319-325.

9. Foil, L. D. 1989. Tabanids as vectors of disease agents. Parasitol. Today 5:80-96.

10. Hannoun, C., R. Panthier, and B. Corniou. 1966. Isolation of Tahyn̆a virus in the south of France. Acta Virol. 10:362-364.

11. Heukeshoven, J., and R. Dernick. 1988. Improved silver staining procedure for fast staining in PhastSystem. Electrophoresis 9:28-32.

12. Karabatsos, N. 1985. International catalogue of arboviruses, including other viruses of vertebrates, 3rd ed. American Society for Tropical Medicine and Hygiene, San Antonio, Tex.

13. Krinsky, W. L. 1976. Animal disease agents transmitted by horse flies or deer flies (Diptera: Tabanidae). J. Med. Entomol. 13:225-275.

14. Le Goff, F., M. Marjolet, J. Guilloteau, I. Humphery-Smith, and C. Chastel. 1990. Characterization and ecology of mosquito spiroplasmas from Atlantic biotopes in France. Ann. Parasitol. Hum. Comp. 65:107-110.

15. Le Goff, F., M. Marjolet, I. Humphery-Smith, M. Leclercq, C. Hélias, F. Supplisson, and C. Chastel. 1993. Tabanid spiroplasmas from France: characterization, ecology and experimental study. Ann. Parasitol. Hum. Comp. 68: $150-153$.

16. Lowry, O. H., N. J. Rosebrough, A. L. Farr, and R. J. Randall. 1951. Protein measurement with the Folin phenol reagent. J. Biol. Chem. 193:265-275.

17. McCoy, R. E., H. G. Basham, J. G. Tully, D. L. Rose, P. Carle, and J. M. Bové. 1984. Acholeplasma flonim, a new species isolated from plants. Int. J. Syst. Bacteriol. 34:11-15.

18. O'Farrell, P. Z., H. M. Goodman, and P. H. O'Farrell. 1977. High resolution two-dimensional electrophoresis of basic as well acidic proteins. Cell 12: 1133-1142.

19. Purcell, R. H., D. David-Robinson, D. C. Wong, and R. M. Chanok. 1966. A color test for the measurement of antibody to the non-acid human mycoplasma species. Am. J. Epidemiol. 84:51-66.

20. Rose, D. L., J. P. Kocka, N. L. Somerson, J. G. Tully, R. F. Whitcomb, P. Carle, J. M. Bové, D. E. Colflesh, and D. L. Williamson. 1990. Mycoplasma lactucae sp. nov., a sterol-requiring mollicute from a plant surface. Int. J. Syst. Bacteriol. 40:138-142.

21. Rose, D. L., J. G. Tully, J. M. Bové, and R. F. Whitcomb. 1992. A modified test for determination of sterol and fatty acid requirements of mollicutes. IOM Lett. 2:232.

22. Tully, J. G., J. M. Bové, F. Laigret, and R. F. Whitcomb. 1993. Revised taxonomy of a monophyletic cluster of arthropod-associated mollicutes to ordinal rank (Entomoplasmatales ord. nov.), with provision for familial rank to separate species with nonhelical morphology (Entomoplasmataceae ord. nov.) from helical species (Spiroplasmataceae), and emended description of the order Mycoplasmatales, family Mycoplasmataceae. Int. J. Syst. Bacteriol. 43:378-385.

23. Tully, J. G., D. L. Rose, P. Carle, J. M. Bové, K. J. Hackett, and R. F. Whitcomb. 1988. Acholeplasma entomolophilum sp. nov. from gut contents of a wide range of host insects. Int. J. Syst. Bacteriol. 38:164-167.

24. Tully, J. G., R. F. Whitcomb, T. B. Clark, and D. L. Williamson. 1977. Pathogenic spiroplasmas: cultivation and vertebrate pathogenicity of a new spiroplasma. Science 195:892-894. 